\title{
Developing a scale for measuring influential factors towards geotourism development
}

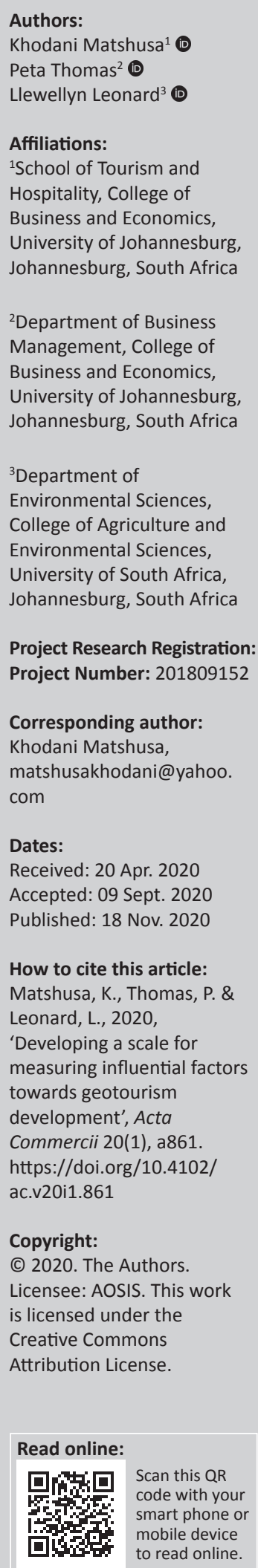

Orientation: This article provided a theoretical enhancement for geotourism development positing the geotourism development index that contributed to gaining understanding of geotourism development by different stakeholders.

Research purpose: To establish and delineate a measurement scale of factors and subsequent variables that influenced geotourism development.

Motivation for this study: Geotourism has been recognised as a branch of sustainable tourism that can be used for local social sustainability through job creation, poverty alleviation, geoconservation and the development of rural economies. Effective geotourism was impossible without understanding the factors influencing geotourism development. Developing the measurement scale for measuring influential factors was deemed important in understanding and towards geotourism development.

Research design, approach and method: Quantitative data were collected from 105 volunteering respondents in order to understand their perceptions of the influential factors in the context of geotourism in a South African national park. Consequently, a statistical analysis using exploratory factor analysis was performed through the principal axis factoring data extraction method to determine factors to establish a measurement scale for influential factors towards geotourism development.

Main findings: The research proposed a measurement scale for measuring the influential factors towards geotourism development.

Practical/managerial implications: Theoretically, this article consolidated the knowledge and understanding of the concept of geotourism development for South African national parks and other stakeholders such as the National Department of Tourism, local communities and academic institutions. Practically, this research emphasised the importance of geotourism-influential factors as mechanisms to develop geotourism and stimulate interest from tourists.

Contribution/value-add: Geotourism concept has been under-researched and no previous research has comprehensively and systematically determined the influential factors of geotourism in an African national public park proposing a quantitative measurement scale towards geotourism development with such parks as public resources for abutting communities.

Keywords: Kruger National Park; South Africa; geotourism; sustainability; national park survey.

\section{Introduction}

The primary aim of this article was to explore and identify factors in a measurement scale to measure the influencers of geotourism development of an African national park. This article looked at developing a measurement scale for determining the influential factors and subsequent variables that can be used to support geotourism development with a focus on the Kruger National Park (KNP) as a case study.

Geotourism is a form of tourism that sustains and enhances the identity of a territory, by taking into consideration the territory's geology, environment, culture, aesthetics, heritage and the wellbeing of its local surrounding residents (European Geoparks Network 2011). Previous studies (Ehsan, Begum \& Leman 2016; Ngwira 2015; Reimold, Whitfield \& Wallmach 2006) concur that geotourism is a branch of sustainable tourism that can be used for poverty alleviation, geoconservation and the development of rural economies. Furthermore, this study adds to the 
tourism literature to identify African national parks such as the KNP as a public resource not only famed for its wildlife but also with the potential to be a geopark. The United Nations Educational Scientific and Cultural Organization (UNESCO) Global Geoparks (UGGp) defined geopark territory as 'single, unified geographical areas where sites and landscapes of international geological significance are managed with a holistic concept of protection, education and sustainable development' (UNESCO 2018).

The need to understand tourist behaviour and their decisionmaking processes has seen a number of studies focussed on tourists' motivations (Njagi, Ndivo \& Manyara 2017:2) as these may assist in tourism product development, improved marketing strategies, enhanced service delivery approaches and the creation of a competitive advantage over other destinations offering similar products or services (Van Vuuren \& Slabbert 2011:295). Based on literature reviewed (Clawson 1972; Kruger \& Saayman 2014; Stemberk et al. 2018), policies and management plans for tourism, including geotourism development, have to take into account the influential factors and impacts (positive and negative) of tourism at national parks if these are to be developed as destinations. The tourism system (tourism actors [particularly sustainability of abutting communities to a park], geotourism places of interest in parks, businesses arising from this as well as the geotourism preferences of the tourists themselves) contributes to the production of new geotourism heritage management systems (heritage places such as important grave sites, dinosaur fossils, geographic points of interest, cultural practices and their actors) that function according to specific geographical context needs as regards meeting all types of stakeholder expectations (Gravari-Barbas 2018). This sentiment is linked to this article's objective of identifying factors that can be used to catalyse geotourism development. The potential contribution to local sustainable development from use of these national geoheritage sites is not being realised. The development of a measurement scale to measure the influential factors towards geotourism development within the KNP hopes to provide an opportunity to sustain and diversify the current tourism market, thereby improving the competitiveness of the organisation through geotourism products. As a result, this study links with the United Nations 2030 agenda, especially with Sustainable Development Goals (SDGs) 1, 2, 8, 9, 10 and 15.

The subsequent delineation presents a literature review detailing the concept of geotourism, research method and design, results, discussion, recommendations and conclusions. Acknowledgements, ethical considerations and cited references are also provided.

\section{Literature review}

The concept of tourist influential factors incorporates the theory that people travel because they are pushed into making this decision by internal forces and pulled by external forces of the destination attributes (Njagi et al. 2017; Phau,
Lee \& Quintal 2013; Uysal \& Jurowski 1994). In this paradigm, the push theory implies that tourists are pushed by their own needs towards destinations where they expect their needs will be satisfied (Njagi et al. 2017). Pull factors, on the other hand, are forces that drive an individual tourist to select a specific place over others as a tourist destination (Phau et al. 2013:271). Push factors are viewed as relating to the needs and wants of the traveller, such as the desire for escape, rest, relaxation, adventure, prestige, health, fitness and social interaction. Pull factors, on the other hand, have been characterised by unique attributes of the destination itself (Klenosky 2002:385). The existence of a rich historic, cultural and geographic heritage, such as geotourism, offers is considered, sometimes even over-deterministically, as one of the most important factors for tourism development (GravariBarbas 2018:5). The relationship between tourism and development of specific geotourism through leveraging heritage is one of the most discussed subjects in recent years by the academic tourism literature (Rozenkiewicz, Widawski \& Jary 2020; Santa-Cruza \& Lopez-Guzman 2017; Santangelo \& Valente 2020; Widawski et al. 2020).

Worldwide research reveals that contemporary tourists seek authentic travel experiences (Chingombe \& Taru 2018; Phau et al. 2013; Reimold 2001; Stokes, Cook \& Drew 2003) and geotourism can provide such an authentic experience (Ginting \& Febriand 2018). Newsome, Dowling and Leung (2012) note that

$[I] \mathrm{n}$ recent years there has been a rapid expansion of tourism interest in geological features and landscapes, both within existing protected areas due to the recognition and identification of geosites via geo-conservation activities, governmental recognition of geo-heritage and the emergence of a complex tourism demographic that is more demanding of new, unique and educative experiences. (p. 20)

Surrounding what is considered as geoheritage, Lima, Brilha and Salamuni (2010) note

[T] he UNESCO's Convention concerning the protection of the world cultural and natural heritage, signed in Paris in 1972, was the first international effort to select sites of paramount world importance due to their natural characteristics. (p. 1)

Carcavilla et al. (2009) note that globally, a minority of countries do see geoheritage conservation as an essential activity and currently, three international programs working with International Union of Conservation of Nature (IUCN) programmes are creating opportunities to protect geological (geo) heritage as follows: the UNESCO World Heritage Convention, the Biosphere Reserves and Wetlands of International Importance (Ramsar Agreement).

Ruban (2015) summarised the number of journal articles published globally on geotourism between 2012 and 2014 and found that there was limited research conducted on the subject. From the article summary, it was found that there are 179 published articles on geotourism in Europe, 104 on Asia and 29 on Africa. Only approximately 10 of the publications on Africa dealt with South African geoheritage. 
It is clear that there is paucity of information in South Africa in terms of realising the potential from geotourism by undertaking empirical research to guide its development. Geotourism can assist to create local enterprises and new jobs (Dowling \& Newsome 2010; UNESCO 2016) and educate tourists and local people on the need to protect geopark attributes. For example, geotourism has been effectively utilised to establish local enterprises and educate tourists and local people in order to promote conservation of geoheritage sites in Europe, Asia, Australia and Canada (Newsome et al. 2012; Rozenkiewicz et al. 2020; Santangelo \& Valente 2020; Widawski et al. 2020).

Given that geotourism is so important, there were several strong motives for researching the factors and subsequent variables that can influence the measurement scale for geotourism development and for choosing the KNP as a case study. Firstly, no study has investigated the measurement scales that may influence or hinder geotourism development at the KNP. Therefore, there is a need to address a conundrum of intertwined endogenous and exogenous conditions as a strategy for enhancing the viability of community-based geotourism projects (Mukwada \& Sekhele 2017). This article contributes by filling this gap as it identifies a quantitative measurement scale based on factors and subsequent variables to measure the potential of a national park for geotourism development. Secondly, the current knowledge of heritage resources, especially geotourism within protected areas, is extremely limited (South African Heritage Resources Agency [SAHRA] 2017:20). Generally, national parks, especially in African countries, are managed and financed by national and/or provincial governments. As public resources often are located in relatively remote and poor rural areas, national parks ought to be available and accessible to the countries' citizens, especially living in communities abutting the parks to leverage value for local community sustainability, conservation and economic development. According to Ngwira (2020) and Reimold (2001), South Africa has abundant natural resources that are not utilised for educational, recreational or tourism purposes. This indicates great potential for natural attractions such as geoheritage sites in the KNP, which have not been utilised by South African parks. Schutte (2009) indicates that few local or international tourists know about the KNP as a geopark leveraging geological history and the cultural heritage of the park. This could be because of the fact that research in the KNP focuses predominantly on biophysical issues and to date insufficiently on the social-ecological issues of the park (Smit et al. 2017:10). In addition, geotourism in South Africa has not as yet been effectively developed and promoted by the National Department of Tourism (NDT) or explored as a potential by the KNP management. Reasons for this include lack of institutional and public participation in heritage concepts (Ngwira 2020; Reimold 1999), lack of data on important geological or geomorphological sites (Schutte \& Booysen 2010) and problems with prescribing relevant legislation to manage these precious places (Cairncross 2011:204). In addition, although some strategic, legislative framework for protecting South Africa's heritage resources has been in operation for more than a decade, it has neither achieved a valuable level of heritage management and protection nor achieved the adequate development of a related heritage geotourism sector (National Department of Science and Technology [NDST] 2012:20). Thirdly, whilst the National Tourism Sector Strategy (NTSS) of South Africa recognises the tourism sector's potential to bring about community economic growth and employment creation (NDT 2017), the main focus for visitors at the KNP is still wildlife viewing (Grünewald, Schleuning \& Böhning-Gaese 2016; Scholtz, Kruger \& Saayman 2014). Neglecting the importance of developing geotourism potentially misses an opportunity to fully achieve sustainable tourism-related business development for surrounding communities. The findings of this article are a contribution to the limited literature on South African parks' potential as geoparks for opportunities related to geotourism valuable in helping to ensure long-term sustainability for related community business competitiveness and local community inclusion.

The KNP is located in the north-eastern corner of South Africa. The park is the largest national park in Africa and one of the top tourist destinations in the world (SANParks 2018; Smit et al. 2017:3). Abutting communities could benefit from the KNP as a public resource (United Nations 2015). As a result, parks (geoparks) as public resources must be available for leverage by local abutting communities so that the following 2030 SDGs 1 (poverty alleviation), 2 (ending hunger), 8 (sustainable economic growth and job creation), 9 (infrastructure development), 10 (reduce inequality) and 15 (protection of natural resources) can be realised. For instance, as regards untapped geotourism potential, for the Venda communities abutting the north of the KNP (Figure 1), there are exemplary geoheritage sites with both very high geotourism and cultural values currently totally un-utilised for geotourism, for instance (see yellow indicators in Figure 1):

- Thulamela (no.1), showing circular sandstone wall reconstruction of Venda chief's home and traditional court;

- Shaluka (no.5) and Nkovakulu (no.11), revealing spectacular vesicular and amygdaloidal basalt packed in circular form, indicating ruins of old dwellings of Venda people;

- Makahane (no.9), dinosaur remains;

- A basalt sofa (no.13), formed by a volcano millions of years ago;

- Mashikiri (no.12), rock art lines inside the concave cave, indicating the presence of the ancient life of hominids;

- Kremetart (no.14), presenting ancient graves, portholes and important geological structures such as beddings, joints, faults and ripple marks;

- Malonga Diamond Prospecting Pit (no.15), offering gemstones and natural spring as attractions.

Definitions of geotourism have evolved as tourist began to focus on geological heritage and geoconservation, 


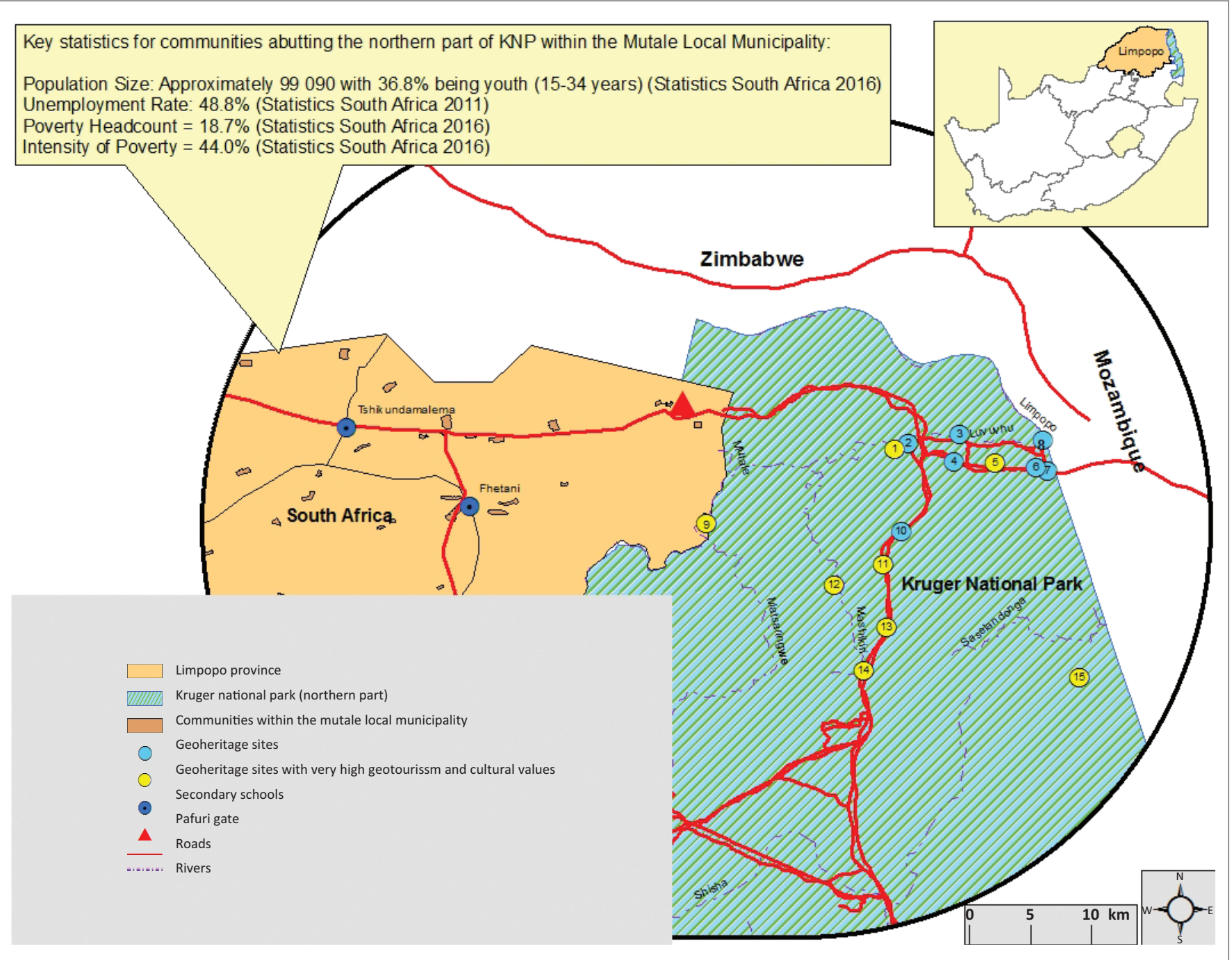

1, Thulamela; 2, Bobomeni Waterfall; 3, Old Pafuri Tent Camp; 4, Basalt Boulder; 5, Shaluka; 6, Botchers Store; 7, Wenela; 8, Crooks Corner; 9, Makahane; 10, Baobab Hill; 11, Nkovakulu; 12, Mashikiri; 13, A basalt sofa; 14, Kremetart; 15, Malonga Diamond Prospecting Pit.

FIGURE 1: Map of the northern part of KNP indicating the study area, geoheritage sites and abutting communities.

incorporating notions such as understanding others' cultures, personal education and sustainability in terms of the importance of recognising the need to preserve such sites and indigenous communities who cohabit with or near it (Hose 2016; Newsome et al. 2012). As it evolves, several definitions for geotourism have been proposed (Boley, Nickeson \& Bosak 2016; Gordon 2018; Ruban 2015), often using terminologies such as geodiversity, geoconservation, geoheritage and geosite in different ways, but what the concepts of geotourism and geoheritage encompass is widely argued in literature (Brilha 2018).

Dowling and Newsome (2010) suggest that geotourism can be divided into two parts: thus, geo and tourism: 'geo' means geomorphology, whilst 'tourism' refers to visiting, learning, appreciating and engaging with geosites.

However, this has a lack of emphasis on the well-being of residents as historic guardians of a geological area with their associated culture. Ehsan, Leman and Begum (2013:1713) capture this omission by better defining geotourism as a 'tool for sustainable development of geoheritage resources'. Hose (2012:4) claims that no studies have adequately covered the 'current breadth of modern geotourism in terms of the nature of [local community] provision and geographical coverage, together with its theoretical underpinnings', which this study addresses. This definition is in line with Jimura (2011). For this research, according to Pacione (2001:356), local community is: 'a group of people who share a geographic area and are bound together by common culture, values, race or social class'. Establishing a measurement scale that encompasses evaluating development factors of a geopark such as the KNP that then guides the development of geotourism to the benefit of local communities becomes critical.

\section{Research method and design Scale development process}

This research was exploratory in nature (Jennings 2010). According to Jennings (2010:17), the exploratory method 'is conducted when very little or no information or data exist on the tourism phenomenon being investigated'. This is most 
suitable to this article as the concept of geotourism is new (Ruban 2015), and although there is much literature suggesting influential factors for other areas of tourism, there are no current academic studies, which specifically determined influential factors towards geotourism in South Africa.

Constructs reflecting important concepts of geotourism were identified from reviewed literature. Ashley and Boyd (2006:70) describe quantitative research as a technique that is an analytical and objective measurement of observable phenomena. As such, because of the absence of a standardised quantitative survey for investigating potential for geotourism development, previous studies were used to construct the exploratory research instrument. In this study, questions were grouped and synthesised into seven main constructs based on previous geotourism-related studies as shown in Table 1 to gain an insight into what potential tourists do, want or desire of national park geotourism activities (only people who visited national parks could partake in the survey) and to understand geotourism as a tourism product of a national park. It is anticipated that the findings and recommendations emanating from this study would help guide what is needed for future geotourism development.

Consequently, the online questionnaire used during the survey consisted of seven sections:

- Section A (Demographics of respondents): Background information about the respondents was collected in order to understand their demographic characteristics (Božic \& Tomic 2015:537; Yao 2013:29).

- Section B1 (Knowledge on geotourism): Respondents were assessed based on their geotourism knowledge in order to measure their knowledge on geoheritage issues (Božic \& Tomic 2015:540).

- Section B2 (Motivations in relation to [undertaking] geotourism): The construct on motivations in relation to geotourism was measured using the different items as suggested by Cheung (2016), Stokes et al. (2003) and Yao (2013). Items were answered using a 5-point Likert scale ranging from 1 through 5 with $1=$ 'not at all influential' and $5=$ 'extremely influential'.

- Section B3 (Visitor attributes and behaviour when visiting geoheritage sites): The visitors' attributes and behaviours when visiting geoheritage sites were assessed by using three separate scales: one assessed the visitors' attributes towards geoheritage sites (Yao 2013) at the KNP

TABLE 1: Survey constructs and authors.

\begin{tabular}{ll}
\hline Construct & Sources \\
\hline Demographics of respondents & Božic and Tomic (2015); Yao (2013) \\
$\begin{array}{l}\text { Knowledge on geotourism } \\
\text { Motivations in relation to geotourism }\end{array}$ & $\begin{array}{l}\text { Božic and Tomic (2015) } \\
\text { (2013) }\end{array}$ \\
$\begin{array}{l}\text { Visitor attributes and behaviour when } \\
\text { visiting geoheritage sites }\end{array}$ & $\begin{array}{l}\text { Boley Nickerson and Bosak (2011); Stokes } \\
\text { et al. (2003); Yao (2013) }\end{array}$ \\
$\begin{array}{l}\text { Tour preferences in relation to } \\
\text { geotourism }\end{array}$ & $\begin{array}{l}\text { Cheung (2016) } \\
\text { Potential benefits of geotourism }\end{array}$ \\
$\begin{array}{l}\text { Boley et al. (2011); Ngwira (2015); Stokes } \\
\text { et al. (2003) }\end{array}$ \\
Potential challenges of geotourism & Brilha (2018); Ngwira (2015) \\
\hline
\end{tabular}

(Table 3) by using a 5-point Likert scale ranging from 1 through 5 with $1=$ 'strongly disagree' and $5=$ 'strongly agree', the second assessed attributes or behaviours of visitors towards geotourism (Boley et al. 2011; Stokes et al. 2003) (Table 4) by using a 5-point Likert scale ranging from 1 through 5 with $1=$ 'not at all important' and $5=$ 'extremely important' and the third rated what a visitor would like to have or see when visiting geoheritage sites (Boley et al. 2011; Stokes et al. 2003) (Table 5) by using a 5-point Likert scale ranging from 1 through 5 with $1=$ 'not at all important' and $5=$ 'extremely important'.

- Section B4 (Tour preferences in relation to geotourism): Items for assessing the respondents' tour preferences in relation to geotourism (Cheung 2016) were measured using a categorical scale.

- Section B5 (Potential benefits of geotourism): The construct potential benefits of geotourism were assessed based on different items suggested by Boley et al. (2011), Ngwira (2015) and Stokes et al. (2003) as shown in Table 6. Items were rated using a 5-point Likert scale ranging from 1 through 5 with $1=$ 'strongly disagree' and $5=$ 'strongly agree'.

- Section B6 (Potential challenges of geotourism): The potential challenges of geotourism were rated based on items (Table 7) developed from findings by Brilha (2018) and Ngwira (2015). Items were rated using a 5-point Likert scale ranging from 1 through 5 with 1 = 'strongly disagree' and $5=$ 'strongly agree'.

The following steps were followed to validate the instrument as recommended by Bonn et al. (2007). Table 1 constructs had been derived from multi-country research but not African research (African national parks were the focus of the index development). It was necessary to pre-test the items for content and face validity undertaken as follows:

- Content validity: an in-depth literature analysis was performed to identify the relevant influential factors towards geotourism (Table 1), including those relating to the African national parks and the KNP, because of the absence of a standardised questionnaire for measuring factors influencing geotourism development at the KNP.

- Face validity: The specialist statistical service consultancy at the University of Johannesburg and professionals working at the South African National Parks (SANParks) assessed and advised on the formulation of the questionnaire and measuring scales before field work was conducted to ensure that the data collected was credible. Some items were considered redundant and dropped as a result of the face validity exercise.

The revised scale items were then tested for the reliability of the identified factors and subsequent variables, by calculating the reliability coefficients (Cronbach's alpha).

\section{Data collection}

The survey sample was obtained from volunteering respondents who completed the online questionnaire hosted 
by SANParks on their social media platforms (Twitter and Facebook) for 3 months in 2019 from 03 July 2019 to 20 September 2019. The respondents were considered representative of tourists who had visited or intend to visit South Africa's national parks showing interest in visiting the national parks by accessing the SANParks' social media feeds to gain information. These respondents were deemed suitable to gauge their interest in the opportunity for geotourism development. Only adult respondents (18 years and above) were allowed to complete the questionnaire.

Although sample size is a significant consideration in factor analysis, there are different views and several criteria used. The lack of consensus is noted by Hogarty et al. (2005:203), who noted that these 'different [sample size] approvals have not served researchers well'. Hair et al. (2007:172) suggested that sample sizes should be 100 or greater. Sapnas and Zeller (2002:135) suggested that even 50 cases may be adequate for factor analysis. At the end of the online survey period on the SANParks' social media pages, 1015 people were captured using the survey software as viewing the online survey. However, only 207 started to answer the online survey, whilst 808 read the survey research description preamble but did not begin the survey. Of the 207 respondents who started to complete the survey, 102 questionnaires were incomplete and thus were not used in the statistical analysis. The rate of completion was a limitation and was because of the lack of tourist education about what geotourism actually is (Božic \& Tomic 2015; Cheung 2016; Reimold 2001; Ruban 2015; Schutte 2009). However, 105 respondents fully completed the questionnaire (completion rate of 50.7\%) and these 105 were used in the statistical analysis. It was also noted that the number of valid cases varied slightly as shown in the reported findings because of occasional missing responses. The average time to complete the survey was 14 minutes.

\section{Statistical data analysis}

Quantitative data collected using the online survey were exported automatically from the online survey software (Questionpro.com 2019) to Excel ${ }^{\mathrm{TM}}$ and analysed using the Statistical Package for Social Sciences (SPSS, 2019) software (version 26) by the specialist statistical service consultancy Statskon at the University of Johannesburg (UJ). The Questionpro software allowed for both capturing and exporting the quantitative data captured in the survey per respondent.

Explanatory factor analysis (EFA) was conducted to determine the underlying structure of variables influencing the perceptions of tourists regarding the influential factors towards geotourism development at a national park. To determine whether a factor analysis could be conducted, Bartlett's test of sphericity and Kaiser-Meyer-Olkin (KMO) measure of sampling adequacy were performed. According to Bartlett (1954), a factor analysis is appropriate when the result of the Bartlett test for sphericity indicates significance $(p<0.05)$. In addition, Kaiser (1970) explains that the minimum value of the KMO (the measure of sampling adequacy) for a factor analysis to be performed should be 0.6. In order to determine the factors from the respective data variables, the pattern matrix of the Principal Axis Factoring (PAF) data extraction technique was applied. The Kaiser normalisation (eigenvalues 1.0 or above) guided the decision on the amount of factors retained. To name the factors, according to Dancey and Reidy (2004:431), a decision should be made on how strong the factor loadings must be to be included in a factor, but this tends to be arbitrary and varies amongst authors. All variables with a factor loading of 0.4 or above were considered as contributing to a factor and all with loadings lower than 0.4 as not correlating significantly with this factor (Steyn 2000) and deleted from the analysis. In addition, any item that cross-loaded onto two factors, with factor loadings of 0.4 or above, was categorised in the factor where interpretability was best. The reliability or internal consistency of all the factors was measured using Cronbach's alpha coefficient $\alpha$. George and Mallery (2003:231) provide the following guidelines for Cronbach's alpha results: > 0.9 - Excellent; > 0.8 - Good; > 0.7 - Acceptable; > 0.6 Questionable; > - 0.5 - Poor; <- Unacceptable.

\section{Ethical consideration}

This article was part of the PhD study that begun in 2018 and there were no ethical permit numbers required, but an ethical clearance was confirmed by the department. In order to obtain quantitative data from tourists, a request was made to SANParks to use their database of tourists in order to administer the questionnaire using an online system. In order to avoid raising any expectations, the respondents were informed in line with UJ's policies that their participation is voluntary and made aware that this work is solely for research and they should not expect any rewards for their participation. Respondents were not forced to answer questions they were not comfortable answering (the online survey allowed respondents to skip questions). All the personal information about participants was kept anonymous to protect their identity, both in this study and in any subsequent academic publications (Nr STH039).

\section{Results}

This section presents the profile of respondents as well as the findings of the factor analysis.

\section{Sample profile (Demographics of respondents)}

The sample demographic characteristics indicate that $57 \%$ $(n=59)$ of the respondents are female and $43 \%(n=45)$ are male, whilst 1 was missing. In terms of race, $67 \%(n=68)$ of the respondents are white people, followed by $25 \%(n=25)$ respondents who are black people, $5 \%(n=5)$ are Indian or Asian and $3 \%(n=3)$ are mixed race, whilst a total of 4 responses were missing. 


\section{Factor analysis}

The pattern matrix of the EFA extraction technique using principal axis factoring and Oblimin rotation with Kaiser normalisation identified factors for each construct. These were labelled according to similar variables or items (Tables $2-7)$. These factors accounted for more than $50 \%$ of the total variance for all the constructs. All factors indicated very good reliability with Cronbach alphas above 0.9 and the KMO measure of sampling adequacy was all above the commonly recommended value of 0.6 , indicating that the items correlated with each other (Kaiser 1970). In all the cases, the BTS was significant $(p=0.000<0.05)$, supporting the favourability for conducting factor analysis (Bartlett 1954).

The last section (sample profile) highlighted the construct on demographic information of respondents, whilst this section (factor analysis) presents the results of explanatory factor analysis (EFA) in order to determine the influential factors towards geotourism development at a national park. The next section (Table 2) unpacks the identified factors for construct 2 (motivation in relation to geotourism).

\section{Construct 2: Motivation in relation to geotourism}

As shown in Table 2, the following five factors were determined as motivations in relation to geotourism: geoheritage, culture and social responsibility (Factors 1), personal education and stimulation (Factor 2), rurality and exercise (Factor 3), accessibility and facilities (Factor 4) and safety and security (Factor 5).
The EFA extraction technique (see section on factor analysis) resulted in five identified factors as motivations in relation to geotourism (Table 2). The next section deals with factors identified on visitors' attributes and behaviour when visiting geoheritage sites (construct 3).

\section{Construct 3: Visitors' attributes and behaviour when visiting geoheritage sites}

For construct 3, three scales were used, one assessed the visitors' attributes towards geoheritage sites (Table 3), the second assessed the important attributes or behaviours of visitors towards geotourism (Table 4) and the third rated the most important visitor likes (Table 5). Firstly, natural characteristics (Factor 1) and accessibility and conservation (Factor 2) were identified as the most important visitors' attributes towards geoheritage sites.

Secondly, as shown in Table 4, representativeness of geoheritage sites (Factor 1) and entertainment for children (Factor 2) emerged as the most influential attributes towards geotourism.

Thirdly, the findings indicate that service and facilities (Factor 1) and urban and sophisticated preferences (Factor 2) were identified as the most important visitor likes when visiting geoheritage sites (Table 5).

This section discussed the identified factors influential on visitors' attributes and behaviour when visiting geoheritage sites (Tables 3-5). The next section reveals the identified factors for construct 4 (potential benefits of geotourism).

TABLE 2: Factor analysis for motivation in relation to geotourism.

\begin{tabular}{|c|c|}
\hline Factors & Result \\
\hline \multicolumn{2}{|l|}{ Factor 1: Geoheritage, culture and social responsibility } \\
\hline To experience a site where natural, historic and cultural aspects have been preserved & 0.757 \\
\hline To visit a destination valued by most people (i.e. World Heritage) & 0.649 \\
\hline To visit destinations offering unique historical or cultural sites compared to other destinations & 0.638 \\
\hline To experience people, lifestyles, languages and cultures very different from my own & 0.634 \\
\hline To visit places where I can experience historic, art galleries, museums, charming towns or locations & 0.620 \\
\hline To visit geoheritage sites that are socially and locally oriented (e.g. employment of local people and support 1) & 0.562 \\
\hline \multicolumn{2}{|l|}{ Factor 2: Personal education and stimulation } \\
\hline To satisfy my curiosity & -0.799 \\
\hline To visit destinations offering a unique bundle of geological features and attractions compared to other destinations & -0.781 \\
\hline To obtain intellectual stimulation & -0.763 \\
\hline To have a memorable experience & -0.630 \\
\hline To increase my knowledge of geological sites and landforms & -0.553 \\
\hline \multicolumn{2}{|l|}{ Factor 3: Rurality and exercise } \\
\hline To do some exercise & 0.621 \\
\hline To visit remote locations & 0.445 \\
\hline To meet other travellers who share my interests & 0.407 \\
\hline \multicolumn{2}{|l|}{ Factor 4: Accessibility and facilities } \\
\hline To experience high-quality accommodation & 0.787 \\
\hline To visit destinations that are easily accessible & 0.559 \\
\hline To visit large cities & 0.461 \\
\hline \multicolumn{2}{|l|}{ Factor 5: Safety and Security } \\
\hline To visit sites that control the number of people entering & 0.978 \\
\hline To visit a site that has a high level of safety and security & 0.479 \\
\hline
\end{tabular}

KNP, Kruger National Park. 
TABLE 3: Factor analysis for visitors' attributes towards geoheritage sites.

\section{Factors} Result

\section{Factor 1: Natural characteristics}

I value the geoheritage sites at KNP

I value the historical architecture of the geoheritage sites

The geoheritage sites reflect the identity of South Africa

The geoheritage sites are attractive to visit

\section{Factor 2: Accessibility and conservation}

There is adequate parking available near the geoheritage sites

The geoheritage sites are easily accessible

There is clear and visible signage to the geoheritage sites

The geoheritage sites have very good historical information

The geoheritage sites are conserved and/or maintained very well

TABLE 4: Factor analysis for visitors' attributes towards geotourism.

\begin{tabular}{ll}
\hline Factors & Result \\
\hline Factor 1: Representativeness of the geoheritage site & \\
Seeing an aspect of park's heritage & 0.915 \\
Learning about what life was like back then & 0.773 \\
Experiencing a different environment & 0.761 \\
Learning about the history of park & 0.752 \\
Opportunity for me to learn more about the park & 0.738 \\
Having interpretive information available & 0.647 \\
Seeing well-preserved old buildings & 0.639 \\
Factor 2: Entertainment for children & \\
Having children's entertainment available & 0.813 \\
Helping my children learn about the park & 0.656 \\
\hline
\end{tabular}

TABLE 5: Factor analysis for important visitor likes when visiting geoheritage sites.

\begin{tabular}{ll}
\hline Factors & Result \\
\hline Factor 1: Service and facilities & \\
Good information & 0.858 \\
An authentic experience & 0.804 \\
Good quality guiding & 0.604 \\
Good visitor amenities & 0.532 \\
Friendly welcome & 0.528 \\
Factor 2: Urban and sophisticated preferences & \\
Nice cafes & -0.834 \\
Shopping for crafts & -0.826 \\
Well-developed attraction & -0.597 \\
\hline
\end{tabular}

\section{Construct 4: Potential benefits of geotourism}

Local social sustainability benefits (Factor 1) and local economic/business development (Factor 2) were determined as potential benefits of geotourism (Table 6).

Whilst this section explored the construct on potential benefits of geotourism (Table 6), the next section explores the potential challenges of geotourism (construct 5).

\section{Construct 5: Potential challenges of geotourism}

As Table 7 shows, the impacts on nature (Factor 1) and impacts on human (Factor 2) were identified as potential challenges of geotourism development.

\section{Discussion}

This study identified the factors that can influence the development of geotourism at the Kruger National Park. The

TABLE 6: Factor analysis for potential benefits of geotourism.

\begin{tabular}{ll}
\hline Factors & Result \\
\hline $\begin{array}{l}\text { Factor 1: Local social sustainability benefits } \\
\text { I desire a reasonable amount of revenue from geotourism to go into } \\
\text { the hands of the local people }\end{array}$ & 0.981 \\
$\begin{array}{l}\text { The local people should be satisfied with the role geotourism plays in } \\
\text { their community }\end{array}$ & 0.932 \\
$\begin{array}{l}\text { Geotourism must contribute to the integrity of the local community } \\
\text { Geotourism must build cultural pride within the local community }\end{array}$ & 0.928 \\
$\begin{array}{l}\text { Geotourism should provide opportunities for education amongst the } \\
\text { local community }\end{array}$ & 0.905 \\
$\begin{array}{l}\text { The local people's opinions must be considered in the geotourism } \\
\text { planning process }\end{array}$ & 0.882 \\
$\begin{array}{l}\text { I am concerned with whether or not my visit impacts the local } \\
\text { community }\end{array}$ & 0.816 \\
$\begin{array}{l}\text { The local people must have the opportunity to manage geotourism in } \\
\text { their region }\end{array}$ & 0.761 \\
$\begin{array}{l}\text { Hiring local people must be a priority of geotourism-related business } \\
\text { Geotourism-related jobs should be filled by local people }\end{array}$ & 0.743 \\
$\begin{array}{l}\text { I am likely to eat locally grown food } \\
\text { I am likely to buy locally made arts and crafts }\end{array}$ & 0.677 \\
$\begin{array}{l}\text { Factor 2: Local economic/business development } \\
\text { I am likely to use locally franchised restaurants }\end{array}$ & 0.669 \\
\begin{tabular}{l} 
I am likely to use locally franchised hotels \\
\hline
\end{tabular} & 0.494 \\
\hline
\end{tabular}

TABLE 7: Factor analysis for potential challenges of geotourism.

\begin{tabular}{ll}
\hline Factors & Result \\
\hline Factor 1: Impacts on nature & \\
Geotourism has the potential to damage cultural heritage & 0.913 \\
Geotourism can increase loss of biodiversity & 0.677 \\
$\begin{array}{l}\text { Geotourism is associated with the degradation of geoheritage and/ } \\
\text { or natural resources }\end{array}$ & 0.635 \\
Factor 2: Impacts on human & \\
$\begin{array}{l}\text { Geotourism can lead to tourists being exposed to poachers and } \\
\text { dangerous wild animals }\end{array}$ & 0.777 \\
Geotourism can bring up tensions in communities & 0.541 \\
Geotourism can lead to overcrowding & 0.513 \\
Geotourism can lead to a decrease in tourists visiting the park & 0.425 \\
\hline
\end{tabular}

general conclusion was that tourists in this sample were influenced towards geotourism by different factors and the characteristics of the KNP. A different set of factors was found to affect the motivation for visiting a geoheritage site, which includes geoheritage, culture and social responsibility, personal education and stimulation, rurality and exercise, accessibility and facilities and safety and security. This article corroborates the findings that geoheritage and culture (Gravari-Barbas 2018), social responsibility (Ehsan et al. 2016), personal education and stimulation (Hose 2016), rurality and exercise (Reimold et al. 2006; Stokes et al. 2003) and accessibility and facilities (Phau et al. 2013) are considered as some of the main motivational factors for visiting a geoheritage site.

It is clear from the results that visitors' attributes towards geoheritage sites at the KNP are influenced by natural characteristics, accessibility and conservation factors and this is in support of previous research by Stokes et al. (2003) and Newsome et al. (2012). The findings indicate representativeness of geoheritage sites and entertainment for children as influential factors for visitors' attributes towards geotourism. Furthermore, the findings indicate that service and facilities and urban and sophisticated preferences were identified as the important attributes when visiting a geoheritage site (Ginting 
\& Febriand 2018). This is in line with the findings of Klenosky (2002) that pull factors (features, attractions or attributes of the destination itself) are important when visiting a tourism destination.

Local social sustainability benefits and local economic/ business development were determined as factors that influence visitors' attitudes towards the well-being of local people. This is consistent with the findings of Ginting and Febriand (2018:2) that show 'geotourism bringing benefits to the tourist and local people' where tourists obtain a unique travel experience and local people acquire economic benefits from tourist visits (Boley et al. 2011). The factors that can hinder the development of geotourism were impacts on nature and impacts on human that corroborate the results by Christian (2018) and Reynard and Giusti (2018).

Because of the absence of a single, standardised quantitative measurement scale, the factors and subsequent variables indicated in Tables 2-7 are considered suitable for investigating influential factors towards geotourism development.

\section{Recommendations}

This article provides a clear and focussed view of an instrument for measuring the perceptions of tourists on influential factors towards geotourism development at the KNP. This instrument takes into account that the geoheritage, culture and social responsibility, personal education and stimulation, rurality and exercise, accessibility and facilities, safety and security, natural characteristics, accessibility and conservation, representativeness of geoheritage sites, entertainment for children, service and facilities, urban and sophisticated preferences, local social sustainability benefits, local economic/business development, impacts on nature and impacts on human may influence geotourism development.

From a methodological perspective, all these factors are suitable for measuring and analysing tourists' perceptions on influential factors towards geotourism development at the KNP and other geotourism-focussed destinations. As this measurement scale provides different variables for measuring the tourists' views on factors influencing geotourism development, it intends to assist SANParks, local community leaders, the private sector (including existing tour operators) and government departments in achieving a sustainable tourism activity. Findings from this article will enable them to plan, develop and market geotourism according to protect geoheritage sites, improve the well-being of local communities, improve and sustain the current tourism market product deliverables.

\section{Conclusions}

The conclusion that can be drawn from this article is that the influential factors of geotourism (geoheritage, culture and social responsibility, personal education and stimulation, rurality and exercise, accessibility and facilities, safety and security, natural characteristics, accessibility and conservation, representativeness of geoheritage sites, entertainment for children, service and facilities, urban and sophisticated preferences, local social sustainability benefits, local economic/business development, impacts on nature and impacts on human) can play a pivotal role in geotourism development and local social sustainability. This study is the first of its kind to produce a uniquely South African measurement scale that can assist with opening new tourism opportunities such as geotourism for creation of local employment and park management and improve academic knowledge on geotourism. Because of this study, the factors and subsequent variables of geotourism at the KNP are now better understood. The developed method of determining factors influencing geotourism development serves as a guideline for future studies in South African National Parks, national parks on the African continent and also globally. However, there were various potential challenges that can hinder the development of geotourism at the KNP such as lack of public participation and inventory of geoheritage sites.

\section{Acknowledgements}

The authors would like to express gratitude to SANParks for granting the permission to conduct their research and all volunteering respondents who shared their perceptions regarding this research.

\section{Competing interests}

The authors have declared that no competing interest exists.

\section{Authors' contributions}

All authors contributed equally to this work.

\section{Funding information}

The research received no specific grant from any funding agency in the public, commercial or not-for-profit sectors.

\section{Data availability statement}

Data sharing is not applicable to this article as no new data were created or analysed in this study.

\section{Disclaimer}

The views and opinions expressed in this article are those of the authors and do not necessarily reflect the official policy or position of any affiliated agency of the authors.

\section{References}

Ashley, P. \& Boyd, B., 2006, 'Quantitative and qualitative approaches to research in environmental management', Australian Journal of Environmental Management 13(2), 70-78. https://doi.org/10.1080/14486563.2006.9725118

Bartlett, M.S., 1954, 'A note on the multiplying factors for various chi-square approximations', Journal of the Royal Statistical Society 16, 296-298. https://doi. org/10.1111/j.2517-6161.1954.tb00174.x

Boley, B.B., Nickerson, N.P. \& Bosak, K., 2011, 'Measuring geotourism: Developing and testing the geotraveler tendency scale (GTS)', Journal of Travel Research 50, 567578. https://doi.org/10.1177\%2F0047287510382295 
Boley, B.B., Nickeson, N.P. \& Bosak, K., 2016, 'A critical examination exploring the differences between geotourism and ecotourism', Tourism Travel and Research differences between geotourism and ecotourism', Tourism

Bonn, M.A., Joseph-Mathews, M.A., Dai, M., Hayes, S. \& Cave, J., 2007, 'Heritage/ cultural attraction atmospherics: Creating the right environment for the heritage/ cultural visitor', Journal of Travel Research 45(3), 345-354. https://doi. org/10.1177\%2F0047287506295947

Božic, S. \& Tomic, N., 2015, 'Canyons and gorges as potential geotourism destinations in Serbia: Comparative analysis from two perspectives - General geotourists and pure geotourists', Open Geoscience 7(1), 531-546. https://doi.org/10.1515/geo2015-0040

Brilha, J., 2018, 'Chapter 4 - Geoheritage: Inventories and evaluation', in E. Reynald \& J. Brilha (eds.), Geoheritage assessment, protection and management.

Cairncross, B., 2011, 'The National Heritage Resource Act (1999): Can legislation protect South Africa's rare geoheritage resources?', Resources Policy 36(3), 204213. https://doi.org/10.1016/j.resourpol.2011.04.002

Carcavilla, L., Durán, J.J., García-Cortés, A. \& López-Martínez, J., 2009, ‘Geological heritage and geoconservation in Spain: Past, present, and future', Geoheritage 1(75), 1-18. https://doi.org/10.1007/s12371-009-0006-9

Cheung, L.T.O., 2016, 'The effect of geopark visitors' travel motivations on thei willingness to pay for accredited geo-guided tours', Geoheritage 8(3), 201-209. https://doi.org/10.1007/s12371-015-0154-z

Chingombe, W. \& Taru, P., 2018, 'Rural geotourism as an option for development in Phuthaditihaba: Golden Gate National Park Area, South Africa', African Journal of Hospitality, Tourism and Leisure 7(1), 1-11.

Christian, C.S., 2018, 'The Caribbean's geotourism potential and challenges: A focus on two Islands in the region', Geosciences 8(273), 1-12. https://doi.org/10.3390/ geosciences8080273

Clawson, M. (1972). 'Park visits in the coming decades: Problems and opportunities', in $\mathrm{H}$. Elliot (ed.), Second world conference on national parks, proceedings, Yellowstone and Grand Teton National Parks, USA, September 18-27, 1972, pp. 117-126

Dancey, C.P. \& Reidy, J., 2004, Statistics without maths for psychology: Using SPSS for Windows, 3rd edn., Prentice Hall, New York, NY.

Dowling, R.K. \& Newsome, D., 2010, Global geotourism perspectives, Goodfellow Publishers Limited, Woodeaton, Oxford.

European Geoparks Network, 2011, Arouca declaration on geotourism, viewed 03 February 2018, from http://www.europeangeoparks.org/?p=223.

Ehsan, S., Leman, M.S. \& Begum, R.A., 2013, 'Geotourism: A tool for sustainable development of geoheritage', Advanced Materials Research 622-623, 17111715. https://doi.org/10.4028/www.scientific.net/AMR.622-623.1711

Ehsan, S., Begum, R.A. \& Leman, M.S., 2016, 'Competitive advantage of geotourism market in Malaysia: A comparison among ASEAN Economies', Procedia - Social and Behavioral Sciences 219, 228-234. https://doi.org/10.1016/j.sbspro.2016.05.010

George, D. \& Mallery, P., 2003, SPSS for windows step by step: A simple guide and reference. 11.0 Update, 4th edn., Allyn and Bacon, Boston, MA.

Ginting, N. \& Febriand, Y., 2018, 'Implementation of geotourism concept in developing natural tourist attraction at Parbaba Village, Toba's Caldera', IOP Conference Series: Earth and Environmental Science 126, 1-9. https://doi.org/10.1088/1755 1315/126/1/012160

Gordon, J.E., 2018, 'Geoheritage, geotourism and the cultural landscape: Enhancing the visitor experience and promoting geoconservation', Geosciences 8(4), 2-25. https://doi.org/10.3390/geosciences8040136

Gravari-Barbas, M., 2018, 'Tourism as a heritage producing machine', Tourism Management Perspectives 26, 5-8. https://doi.org/10.1016/j.tmp.2017.12.002

Grünewald, C. Schleuning, M. \& Böhning-Gaese, K., 2016, 'Biodiversity, scenery and infrastructure: Factors driving wildlife tourism in an African Savannah National
Park', Biological Conservation 201, 60-68. https://doi.org/10.1016/j. biocon.2016.05.036

Hair, J.F. Jr, Money, A.H., Samouel, P. \& Page, M., 2007, Research methods for business, Wiley, Chichester.

Hogarty, K., Hines, G., Kromrey, J., Ferron, J. \& Mumford, K., 2005, 'The quality of factor solutions in exploratory factor analysis: The influence of sample size, communality, and over-determination', Educational and Psychological Measurement 65(2), 202-226. https://doi.org/10.1177/0013164404267287

Hose, T.A., 2012, 'Editorial: Geotourism and geoconservation', Geoheritage 4(1-2), 1-5. https://doi.org/10.1007/s12371-012-0059-z

Hose, T.A., 2016, Geoheritage and geotourism: A European perspective (heritage matters), Boydell Press, Woodbridge.

Jennings, G., 2010, Tourism research, 2nd edn., John Wiley \& Sons, Milton.

Jimura, T., 2011, 'The impact of World Heritage Site designation on local communities - A case study of Ogimachi, Shirakawa-mura, Japan', Tourism Management 32(2), 288-296. https://doi.org/10.1016/j.tourman.2010.02.005

Kaiser, H., 1970, 'A second generation little jiffy', Psychometrika 35(4), 401-415. https://doi.org/10.1007/BF02291817

Klenosky, D.B., 2002, 'The pull of tourism destinations: A means-end investigation', Journa of Travel Research 40(4), 385-395. https://doi.org/10.1177/004728750204000405

Kruger, M. \& Saayman, M., 2014, 'The determinants of visitor length of stay at the Kruger National Park', Koedoe 56(2), 1-11. https://doi.org/10.4102/koedoe.v56i2.1114

Lima, F.F., Brilha, J.B. \& Salamuni, E., 2010, 'Inventorying geological heritage in large territories: A methodological proposal applied to Brazil', Geoheritage 2(3-4), 9199. https://doi.org/10.1007/s12371-010-0014-9
Mukwada, G. \& Sekhele, N., 2017, 'The potential of community-based geotourism in rural development in South Africa: The case of Witsie cave project', Journal of Asian and African Studies 52(4), 471-483. https://doi.org/10.1177/0021909615595991

National Department of Science and Technology, 2012, South African strategy for the palaeosciences, viewed 07 May 2018, from https://nrfsubmission.nrf.ac.za/nrfmkii/ FormView.aspx?encrypt=zEidFg34odAdcKmcJ18zweqbqDoyliv5PTA+kOuzZlk.

National Department of Tourism, 2017, National tourism strategy, viewed 17 May 2018, from https://www.tourism.gov.za/AboutNDT/Publications/National\%20 Tourism\%20Sector\%20Strategy\%20NTSS\%202016-2026.pdf.

Newsome, D., Dowling, R. \& Leung, Y., 2012, 'The nature and management of geotourism: A case study of two established iconic geotourism destinations', Tourism Management Perspective 2, 19-27. https://doi.org/10.1016/j. tmp.2011.12.009

Ngwira, P.M., 2015, ‘Geotourism and geoparks: Africa's current prospects for sustainable rural development and poverty alleviation', in E. Errami, M. Brocx \& V. Semeniuk (eds.), From geoheritage to geoparks, Case studies from Africa and beyond, pp. 25-33, Springer, Charm.

Ngwira, P.M., 2020, 'A review of geotourism and geoparks: Is Africa missing out on this mechanism for the development of sustainable tourism?' Geoconservation Research 2(1), 29-39.

Njagi, C.W., Ndivo, R.M. \& Manyara, G., 2017, 'Understanding the travel motivation among youth travellers in Kenya: The "push" and "pull" paradigm', African Journal of Hospitality, Tourism and Leisure 6(1), 1-16.

Pacione, M., 2001, Urban geography: A global perspective, Routledge, London.

Phau, I., Lee, S. \& Quintal, V., 2013, 'An investigation of push and pull motivations of visitors to private parks: The case of Araluen Botanic Park, Journal of Vacation Marketing 19(3), 269-284. https://doi.org/10.1177/1356766712471232

Questionpro.com, 2019, Computer software, viewed 29 June 2019, from https:// geotourism.questionpro.com/.

Reimold, W.U., 1999, 'Geoconservation - A Southern African and African perspective', Journal of African Earth Science 29(3), 469-483. https://doi.org/10.1016/S08995362(99)00110-4

Reimold, W.U., 2001, 'Tourism...ecotourism...geotourism! A case for a new national tourism strategy', Geobulletin 44(4), 20-23.

Reimold, U.V., Whitfield, G. \& Wallmach, T., 2006, 'Geotourism potential of Southern Africa', in D. Newsome \& R. Dowling (eds.), Geotourism: Sustainability, impacts and management, pp. 42-62, Elsevier, Oxford.

Reynard, E. \& Giusti, C., 2018, 'The landscape and cultural value of geoheritage', in E. Reynard \& J. Brilha (eds.), Geoheritage: Assessment, protection, and management pp. 147-166. Elsevier, Amsterdam.

Rozenkiewicz, A., Widawski, K. \& Jary, Z., 2020, 'Geotourism and the 21st century NTOs' website information availability on geotourism resources in selected Central European countries: International perspectives', Resources 9(4), 2-28. https://doi.org/10.3390/resources9010004

Ruban, D.A., 2015, 'Geotourism - A geographical review of the literature', Tourism Management Perspectives 15, 1-15. https://doi.org/10.1016/j.tmp.2015.03.005

Santa-Cruza, F.G. \& Lopez-Guzman, T., 2017, 'Culture, tourism and World Heritage Sites', Tourism Management Perspectives 24, 111-116. https://doi.org/10.1016/j tmp.2017.08.004

Santangelo, N. \& Valente, E., 2020, 'Geoheritage and geotourism resources', Resources 9(80), 1-5. https://doi.org/10.3390/resources9070080

Sapnas, K.G. \& Zeller, R.A., 2002, 'Minimising sample size when using exploratory factor analysis for measurement', Journal of Nursing Measurement 10, 135-154. https://doi.org/10.1891/jnum.10.2.135.52552

Scholtz, M., Kruger, M. \& Saayman, M., 2013, 'Understanding the reasons why tourists visit the Kruger National Park during a recession', Acta Commercii 13(1), 1-9. https://doi.org/10.4102/ac.v13i1.168

Schutte, I.C., 2009, 'A strategic management plan for the sustainable development of geotourism in South Africa', PhD thesis, University of North West.

Schutte, I.C. \& Booysen I., 2010, 'Geosite identification as an element of promoting geotourism in a wildlife hotspot: The Kruger National Park, South Africa', in R.K. Dowling and D. Newsome (eds.), Global geotourism perspectives, pp. 124-136. Goodfellow Publishers, Oxford.

Smit, I.P.J., Roux, D.J., Swemmer, L.K., Boshoff, N. \& Novellie, P., 2017, 'Protected areas as outdoor classrooms and global laboratories: Intellectual ecosystem services flowing to and from a national park, Ecosystem Services 28(B), 238-250. https:// doi.org/10.1016/j.ecoser.2017.05.003

South African Heritage Resources Agency (SAHRA), 2017, Summary and analysis of the inventory of the national estate: 2017, viewed 01 May 2018, from https:// www.sahra.org.za/download-attachment/35644

South African National Parks, 2018, Kruger National Park management plan, viewed 29 January 2018, from https://www.sanparks.org/assets/docs/conservation/ park_man/knp/draft-plan.pdf.

Statistical Package for Social Sciences, 2019, Computer software, Version 26, IBM SPSS Statistics. This is a computer software and the details are provided.

Stemberk, J., Dolejs, J., Maresova, P. \& Kuca, K., 2018, 'Factors affecting the number of visitors in national parks in the Czech Republic, Germany and Austria', International Journal of Geo-Information 7(124), 1-10. https://doi.org/10.3390/ijgi7030124

Steyn, H.S., 2000, 'Practical significance of the difference in means', South African Journal of Industrial Psychology 26(3), 1-3. https://doi.org/10.4102/sajip.v26i3.711 
Stokes, A.M., Cook, S.D. \& Drew, D., 2003, Geotourism: The new trend in travel, viewed 18 September 2017, from http://www.egret.us/clinton/Geotourism\%20The\%20 New\%20Trend\%20in\%20Travel.pdf.

United Nations, 2015, Sustainable development goals: 17 goals to transform our world, viewed 27 June 2019, from http://www.un.org/sustainabledevelopment/.

United Nations Educational, Scientific and Cultural Organization, 2016, UNESCO global geoparks: Celebrating earth heritage, sustaining local communities, viewed 08 February 2018, from http://unesdoc.unesco.org/images/0024/002436/243650e. pdf.

United Nations Educational, Scientific and Cultural Organization, 2018, Globa geoparks, viewed 11 June 2018, from http://www.unesco.org/new/en/naturalsciences/environment/earth-sciences/unesco-global-geoparks/.
Uysal, M. \& Jurowski, C., 1994, 'Testing the push and pull factors', Annals of Tourism Research 21(4), 844-846. https://doi.org/10.1016/0160-7383(94)90091-4

Van Vuuren, C. \& Slabbert, E., 2011, 'Travel motivations and behaviour of tourists to a South African resort', International Conference on Tourism and Management Studies, Proceedings, Faro, Algarve, Portugal, October 26-29 2011, pp. 295-304.

Widawski, K., Olesniewicz, P., Rozenkiewicz, A., Zareba, A. \& Jandova, S., 2020, 'Protected areas: Geotourist attractiveness for weekend tourists based on the example of Gorcza 'nski National Park in Poland', Resources 9(35), 1-28. https:// doi.org/10.3390/resources9040035

Yao, Y., 2013, 'Assessing tourist experience satisfaction with a heritage destination', Masters thesis, Purdue University. 